\title{
First Report of CC5-MRSA-IV-SCCfus “Maltese Clone" in Bat Guano
}

\author{
Assia Mairi ${ }^{1,2}{ }^{\oplus}$, Abdelaziz Touati ${ }^{1}$, Alix Pantel ${ }^{3}{ }^{(0}$, Alex Yahiaoui Martinez ${ }^{3}$, Mourad Ahmim ${ }^{4}$, Albert Sotto ${ }^{5} \oplus^{\circ}$, \\ Catherine Dunyach-Remy ${ }^{3}{ }^{(1)}$ and Jean-Philippe Lavigne ${ }^{3, *}$ (i) \\ 1 Laboratoire d'Ecologie Microbienne, Faculté des Sciences de la Nature et de la Vie, Université de Bejaia, \\ Bejaia 06000, Algeria; assia-mairi@hotmail.fr (A.M.); ziz1999@yahoo.fr (A.T.) \\ 2 Bacterial Virulence and Chronic Infection, Institut National de la Santé et de la Recherche Médicale U1047, \\ University Montpellier, 30908 Nîmes, France \\ 3 Bacterial Virulence and Chronic Infection, Institut National de la Santé et de la Recherche Médicale U1047, \\ Department of Microbiology and Hospital Hygiene, University Montpellier, Nîmes University Hospital, \\ 30029 Nîmes, France; alix.pantel@chu-nimes.fr (A.P.); alex.yahiaouimartinez@chu-nimes.fr (A.Y.M.); \\ catherine.remy@chu-nimes.fr (C.D.-R.) \\ 4 Laboratoire d'Ecologie et d'Environnement, Faculté des Sciences de la Nature et de la Vie, \\ Université de Bejaia, Bejaia 06000, Algeria; forestecolo@gmail.com \\ 5 Bacterial Virulence and Chronic Infection, Institut National de la Santé et de la Recherche Médicale U1047, \\ Department of Infectious and Tropical Diseases, University Montpellier, Nîmes University Hospital, \\ 30029 Nîmes, France; albert.sotto@chu-nimes.fr \\ * Correspondence: jean.philippe.lavigne@chu-nimes.fr; Tel.: +33-46-668-3202
}

Citation: Mairi, A.; Touati, A.; Pantel, A.; Yahiaoui Martinez, A.; Ahmim, M.; Sotto, A.; Dunyach-Remy, C.; Lavigne, J.-P. First Report of CC5-MRSA-IV-SCCfus "Maltese Clone" in Bat Guano. Microorganisms 2021, 9, 2264. https://doi.org/ 10.3390/microorganisms 9112264

Academic Editor: Paolo Calistri

Received: 14 October 2021

Accepted: 29 October 2021

Published: 31 October 2021

Publisher's Note: MDPI stays neutral with regard to jurisdictional claims in published maps and institutional affiliations.

Copyright: (c) 2021 by the authors. Licensee MDPI, Basel, Switzerland. This article is an open access article distributed under the terms and conditions of the Creative Commons Attribution (CC BY) license (https:// creativecommons.org/licenses/by/ $4.0 /)$.
Abstract: Methicillin-resistant Staphylococcus aureus (MRSA) is a widespread pathogen that could cause different illnesses in both human and animals. Presence of MRSA in animals raises concerns of their capacity to act as reservoirs, particularly in wild animals. This study aimed to characterize the resistance and virulence patterns of $S$. aureus strains isolated from bat guano in Algeria. From March to May 2016, 98 bat guano samples from Aokas's cave (Bejaia, Algeria) were collected. Swabs were taken for microbiological studies. Isolates were identified by Vitek ${ }^{\circledR}$ MS system, and antibiotic susceptibility was determined by disk diffusion method. The clonal origin, virulence and antibiotic resistance profiles of $S$. aureus isolates were characterized by whole genome sequencing. Eleven S. aureus strains were obtained from the 98 guano samples. Seven isolates were sensitive to all antibiotics tested and four (36.3\%) were resistant to penicillin G, cefoxitin and fusidic acid. The four MRSA isolates were assigned to the sequence type ST149 and related to spa type t010. These isolates harbored a SCCmecIV element and the fusidic acid resistance element Q6GD50 (fusC). They carried different virulence genes including several enterotoxins (sea, egc enterotoxin locus, sec, sel), and the toxic shock syndrome toxin (tst). Our results highlight that bat guano may constitute an important reservoir of MRSA strains.

Keywords: Algeria; bat guano; Maltese clone; toxic shock syndrome toxin; ST149

\section{Introduction}

Staphylococcus aureus can colonize and/or infect human and animals and this bacterium is considered as one of the most serious public health threats [1-3]. In hospital, $S$. aureus represents a frequently occurring pathogen isolated in various samples, and it is also the second most common pathogen in the community [4]. Methicillin-resistant S. aureus (MRSA) has emerged and diffused rapidly in hospitals just after the introduction of penicillin M [4,5]. To date, this MRSA is one of the most important nosocomial pathogens, causing high rates of morbidity and mortality worldwide [1,4]. Subsequently, a set of predominant clones has been characterized. Currently, ST5 and ST239, USA300, and ST398 are the frequently encountered clones in the healthcare-associated MRSA (HAMRSA), the community-associated MRSA (CA-MRSA) and the livestock-associated MRSA (LA-MRSA), respectively [4,5]. 
The expression of different virulence factors, such as the staphylococcal enterotoxins, toxic shock syndrome toxin-1 (TSST-1), hemolysins, and Panton-Valentine leukocidin (PVL) is the main cause of the infectious capacity of $S$. aureus and its success as pathogen [6]. Some MRSA clones have been found to harbor these toxinogenic markers. In parallel, MRSA has emerged in different reservoirs, and is currently disseminated in the community and has been frequently found to colonize or infect animals [3]. Indeed, MRSA has been discovered in pets, livestock, and wild animals $[7,8]$.

Bats are one of the most widespread and diversified mammalian groups, with more than 1300 species, living in a wide variety of habitats and climatic zones $[9,10]$. They play an important role as pollinators of economically important plants and could be used as a source of animal protein [11]. However, bats have also received increasing attention as potential reservoir and vectors of zoonotic microorganisms such as Ebola virus, coronavirus and Marburg virus [12,13]. In addition to the various viruses that have been identified in bats, bacteria of clinical importance have also been described [14,15]. Among the bacteria, S. aureus has been detected in bats [16-21], mainly described in Sub-Saharan African regions. However, the presence of MRSA has rarely been reported [21,22]. In 2007, these strains were first isolated from feces collected from diverse bats in Poland and $23 \%$ of staphylococci were methicillin resistant comprising MRSA and Staphylococcus sciuri [22]. In 2020, a MRSA strain belonging to the CC152 and harboring the PVL was described in different fomites samples (e.g., currency note, computer keyboard, cell phone) in Obafemi Awolowo University, Nigeria with a possible transmission from fruit bats (Eidolon helvum) [21].

In Algeria, the prevalence of MRSA is of concern notably due to the diffusion of the 'European' ST80-IV CA-MRSA PVL+ clone [4]. Recently, our team highlighted the diffusion of toxinogenic MRSA in different ecological niches (humans, pets, livestock, wildlife, food and aquatic environment), suggesting a wildlife MRSA reservoir in this country [8].

The objectives of this study were to: (1) evaluate the presence of S. aureus and MRSA in bat guano in Aokas's cave (Bejaia, Algeria) and (2) characterize the resistome and virulome of the MRSA isolates. This work provides evidence that the multidrug resistance (MDR) is now widespread in a country where the prevalence of MDR bacteria is high. Wild animals represent a reservoir that contributes to the dissemination and transfer of the resistance genes.

\section{Materials and Methods}

\subsection{Fecal Samples}

Between March and May 2016, bat guano samples from Microchiroptera were obtained from Aokas's cave (located $27 \mathrm{~km}$ East of Bejaia city, Algeria). Bats present in caves belong to troglophilic species including Asellia tridens, Rhinolophus blasii, Rhinolophus clivosus, Rhinolophus euryale, Rhinolophus ferrumequinum, Rhinolophus hipposideros, Rhinolophus mehelyi, Rhinopoma hardwickii, Myotis punicus, Myotis capaccinii Myotis emarginatus, Plecotus gaisleri, Taphozous nudiventris and Miniopterus schreibersii. These species overwinter in caves, and during the summer (and the breeding season) they seek warmer shelters (e.g., attics, roofs of houses and mosques) and are in proximity to humans. Aokas's cave is an artificial tunnel that has an entrance in the form of a large natural spherical chamber, with a $113 \mathrm{~m}$ long tunnel on the right side, which leads into the open air through a narrow opening. It is $3.5 \mathrm{~m}$ wide and its height varies from $2 \mathrm{~m}$ to $2.7 \mathrm{~m}$. On the left side is a tunnel of $298 \mathrm{~m}$ length, $3 \mathrm{~m}$ width and $2 \mathrm{~m}$ height. Between the two tunnels, there is a natural narrow crack facing the entrance, perpendicular to the tunnel (Figure 1). This cave is known to shelter bats only. Collection plates (using plastic petri dish with rising edge) were disposed the day before the sampling in the different sites of collection (entry $(n=3)$, center $(n=5)$ and far end $(n=6)$ of the cave). These plates avoided contamination because the guano were not on the cave floor and no insects could reach the fecal pellets and contaminate it. Fresh pellets were collected (14 samplings in 7 periods) in the plates, early in the morning. They were mixed 
using sterile swabs (Copan, Brescia, Italy). All samples were analyzed within the day after sampling in the Microbiological Ecology Laboratory at the University of Bejaia (Algeria).

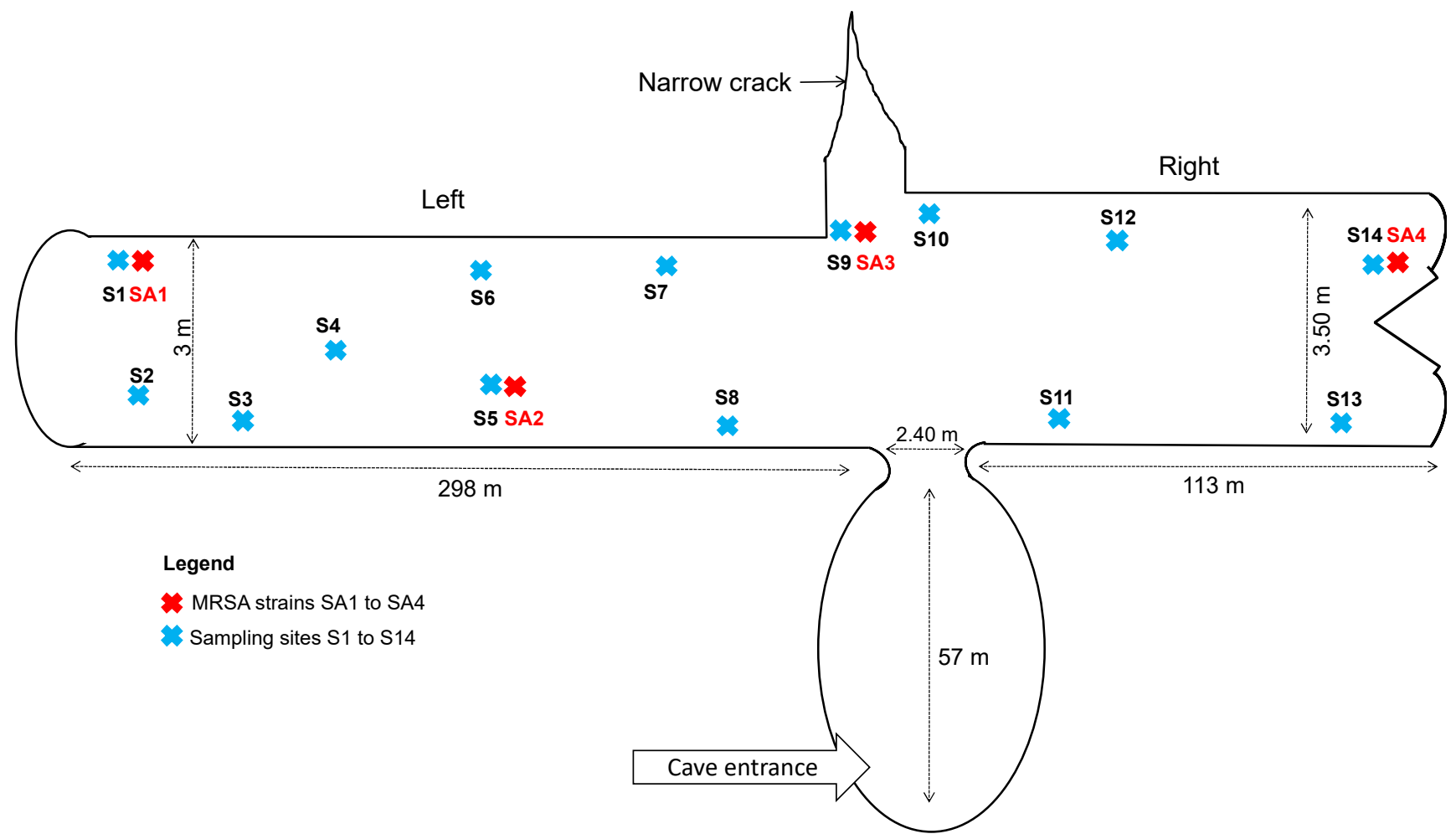

Figure 1. Schematic representation of the Aokas's cave. Sx, site of sampling (x, number); SAx, site of S. aureus isolation (x, number).

Swabs were inoculated in $1 \mathrm{~mL}$ of Trypticase Soy Broth (TSB) (Fluka, St. Louis, MO, USA) containing colistin $(10 \mathrm{mg} / \mathrm{L})$, aztreonam $(10 \mathrm{mg} / \mathrm{L})$ and amphotericin B $(2 \mathrm{mg} / \mathrm{L})$. After $24 \mathrm{~h}$ incubation at $37^{\circ} \mathrm{C}$, a $200 \mu \mathrm{L}$ aliquot was steaked onto mannitol salt agar plates and incubated for $48 \mathrm{~h}$ at $37^{\circ} \mathrm{C}$.

In total, 98 fecal samples were collected. However, due to the sampling method used, we were unable to assign one fecal sample to individual bats. To avoid multiple isolates from one bat, we exclusively included one isolate per sampling site and date in the final analysis.

\subsection{Bacterial Identification}

Bacterial identification was performed on all colonies grown on plates using the Vitek ${ }^{\circledR}$ MS system (bioMérieux, Marcy l’Etoile, France).

\subsection{Antimicrobial Susceptibility Testing}

Antimicrobial susceptibility was determined by the disk diffusion method (BioRad, Marnes La Coquette, France) on Mueller-Hinton agar plates according to European Committee on Antimicrobial Susceptibility Testing (EUCAST) 2019 [23].

The following antibiotics were tested: penicillin $\mathrm{G}(1 \mu \mathrm{g})$, cefoxitin $(30 \mu \mathrm{g})$, erythromycin $(15 \mu \mathrm{g})$, clindamycin $(2 \mu \mathrm{g})$, quinupristin/dalfopristin $(15 \mu \mathrm{g})$, kanamycin $(30 \mu \mathrm{g})$, tobramycin $(10 \mu \mathrm{g})$, gentamicin $(10 \mu \mathrm{g})$, minocycline $(30 \mu \mathrm{g})$, ofloxacin $(5 \mu \mathrm{g})$, fusidic acid $(10 \mu \mathrm{g})$, fosfomycin $(200 \mu \mathrm{g})$, rifampicin $(5 \mu \mathrm{g})$ and cotrimoxazole $(1.25-23.75 \mu \mathrm{g})$. The minimum inhibitory concentration (MIC) values of isolates to vancomycin and teicoplanin were determined by microbroth dilution (Umic ${ }^{\circledR}$, Biocentric, Bandol, France) over a range of dilutions $(0.25-4 \mathrm{mg} / \mathrm{L}$ for vancomycin and $0.25-8 \mathrm{mg} / \mathrm{L}$ for teicoplanin). Resistance to methicillin was evaluated using cefoxitin disks. The detection of mecA and mecC genes was performed by PCR as described [24]. 


\subsection{Whole-Genome Analysis}

The four MRSA isolates were sequenced. The strains were grown aerobically on 5\% Columbia sheep blood agar plates (Becton Dickinson, Le Pont-de-Claix, France) at $37^{\circ} \mathrm{C}$ for $24 \mathrm{~h}$. Genomic DNA was extracted by EZ1 DNA Tissue Kit (QIAGEN, Courtaboeuf, France). Whole Genome Sequencing (WGS) was performed with an Illumina MiSeq sequencing system (Illumina, San Diego, CA, USA) using the paired-end (PE) read libraries (PE250) prepared by Nextera XT DNA Library Prep Kit (Illumina) following the manufacturer's protocol. Raw reads were processed using FastQC (v.0.11.7) to assess data quality. The Cutadapter tool (v.1.16) implemented in Python (v.3.5.2) was used to remove residual PCR primers and filter low quality bases (Q_score $<30)$ and short reads $(<150 \mathrm{bp})$. The filtered trimmed reads were included in the downstream analysis. Obtained reads were mapped against S. aureus NCTC 8325 genome (GenBank accession number: GCA_000013425.1), employing the CLC genomics workbench 7 (Qiagen Inc., Valencia, CA, USA), using default parameters; length fraction: 0.5 , similarity fraction: 0.8 . The assembled contigs were processed by Prokka software for microbial genome annotation [25]. Virulence factor database (VFDB) (https://www.mgc.ac.cn/VFs/, accessed on 26 May 2021) was used to infer virulence factor-encoding genes from genome sequences [26]. Antimicrobial resistance genes were obtained from ABRIcate with the ResFinder database on assembled genomes $[27,28]$. The two whole genomes sequences (WGS) were aligned using the MAFFT software [29]. SNP calls were made from the PE library raw reads. For SNP analysis, we employed the following software: SNP-sites for variants calling [30] and SnpEff (v.1.3T) for SNP annotation in coding regions [31]. SNP annotations of affected genes were searched within wild-type genome and their effects were classified according to mutation impact. Genes affected by stop gain mutations were searched in Uniprot database for virulence classification. Additional analyses were performed on WGS such as circular genome representation (BLAST Ring Image Generator software (BRIG) [32]). Raw reads of newly sequenced MRSA strains are available under the BioProject number PRJNA734263 and assembled genomes SAMN19487653, SAMN19487654 and SAMN19487655.

\section{Results}

A total of 11 S. aureus isolates were studied. Seven S. aureus isolates were sensitive to all antibiotic tested. The four remaining isolates were resistant to penicillin $\mathrm{G}$, cefoxitin and fusidic acid (Table S1). PCR amplification showed that these four isolates were positive for $m e c A$ gene. No mecC gene was detected.

Only the four MRSA isolates were submitted to whole genome sequencing to determine their genetic determinants. The genome sizes obtained varied between 2,734,323 to $2,795,689$ bp with a high similarity (>99\% identity) (Table 1). The four genomes exhibited a similar GC content around $32.7 \%$. The numbers of coding DNA sequences (CDS) were 2498 for B-AoC-SA2, 2539 for B-AoC-SA1, 2541 for B-AoC-SA4 and 2556 for B-AoC-SA3.

Table 1. General genome characteristics of MRSA strains isolated from bat guano.

\begin{tabular}{ccccc}
\hline Features & B-AoC-SA1 & B-AoC-SA2 & B-AoC-SA3 & B-AoC-SA4 \\
\hline Genome size (bp) & $2,777,157$ & $2,734,323$ & $2,795,689$ & $2,776,793$ \\
Genome Coverage & $64.36 X$ & $85.14 X$ & $72.08 X$ & $60.20 X$ \\
Contigs & 35 & 46 & 32.67 & 34 \\
G + C Content (\%) & 32.67 & 32.70 & 2556 & 32.67 \\
CDS & 2539 & 2498 & 61 & 2541 \\
tRNA & 61 & 61 & 149 & 61 \\
MLST & 149 & 149 & Bejaia (Algeria) & Bejaia (Algeria) \\
Locality & Bejaia (Algeria) & Bejaia (Algeria)
\end{tabular}

The circularized maps of the S. aureus strains based on the predicted CDS showed that both genomes exhibited the same overall organization (Figure 2). Each genome presented 
61 rRNA. The four MRSA strains were assigned to the ST149, termed the "Maltese clone" and related to the spa type t010. They also harbored the SCCmecIV element (Table 2).

These isolates carried the putative fusidic acid resistance element, Q6GD50 (fusC), which was correlated with phenotypic resistance to fusidic acid. They also harbored fos $B$ (coding for fosfomycin resistance) and blaZ (coding for penicillinase) genes. For the virulome profile, the whole genome analysis showed that all strains carried the toxic shock syndrome toxin- (tst), enterotoxins- (sea, sec, sel, egc-cluster), leukocidins- (lukF, lukS, $l u k D$, lukE and lukY), adhesion factors- (belonging to the microbial surface components recognizing adhesive matrix molecules) (clfA, fnbA, fnbB, fib, map, eno, bbp, ebh, ebpS, sas $G$, $s d r C, s d r D$ and $v w b)$, and hemolysins-encoding genes ( $h l, h l a, h l l l l, h l b$ and $h \lg A)$. The isolates belonged to the agr type II and harbored the cap5 gene (Table 2). These isolates harbored neither exfoliative toxins-encoding genes $(e t a, e t b, e t d)$, nor epithelial cell differentiation inhibitors (edin $A$, edin $B$, and $e \operatorname{din} C$ ) and $l u k F / S-P V$ genes. The genome analysis confirmed that the four isolates were closely related according to Ankrum et al.'s criteria [33]. Variant call analysis showed the presence of SNPs within coding regions, comparing the four S. aureus isolates. When evaluating SNPs in B-AoC-SA1 strain compared to the three other strains, 58 divergent nucleotides were identified, and affected $2.3 \%$ of the genes (58/2539). Among these differences, 10 SNPs concerned nonsense (Stop gain) mutations affecting genes that were classified according to their functions (virulence factor-encoding genes/other genes). These mutations directly affected one well-known virulence factor (clfB (clumping factor B-encoding gene) in B-AoC-SA1) and other non-virulence factor (hin (DNA-invertase encoding gene), bacC (oxydase-encoding gene), $r n m V$ (ribonucleaseencoding gene), gloB (gluthatione hydrolase-encoding gene), fabG3 (3-oxoacyl-reductase encoding gene), ugp $Q$ (glycerol-phosphodiesterase-encoding gene), lon (ATP-dependent protease-encoding gene), paaZ (phenylacetic aid-coenzyme A encoding gene) and recD (helicase-encoding gene).

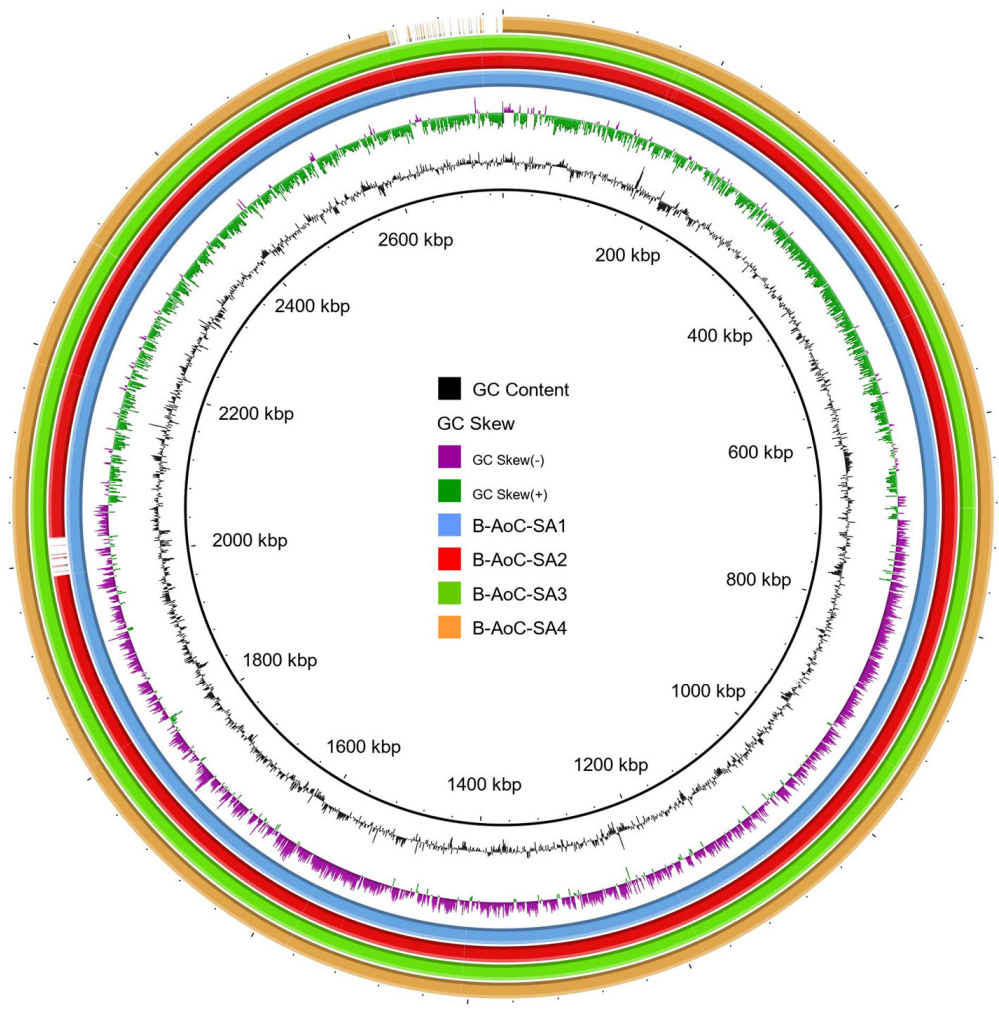

Figure 2. BRIG analysis of MRSA genomes isolated from bat guano. Genomes of B-AoC-SA2 (red ring), 3 (green ring), 4 (orange ring) isolates were compared against the genome of B-AoC-SA1 (blue ring) isolate using BRIG software [32]. Only regions with $>90 \%$ nucleotide identity are colored. Lower identity percentage or no match are represented by blank spaces in each ring. 
Table 2. Characteristics of MRSA isolated from bat guano in Aokas's cave (Bejaia, Algeria).

\begin{tabular}{|c|c|c|c|c|c|c|c|c|c|c|}
\hline Strain Type & Strain & $\begin{array}{c}\text { Date Isolated } \\
\text { and Isolation } \\
\quad \text { Site }^{1}\end{array}$ & $\begin{array}{c}\text { Antimicrobial } \\
\text { Resistance } \\
\text { Phenotype }^{2}\end{array}$ & $\begin{array}{c}\text { Antibiotic } \\
\text { Resistance } \\
\text { Genes }\end{array}$ & $\begin{array}{c}\text { Specific } \\
\text { Toxinogenic } \\
\text { Profile }\end{array}$ & $\begin{array}{l}\text { Leucocidins } \\
\text { Genes }\end{array}$ & $\begin{array}{c}\text { Enterotoxins } \\
\text { Genes }^{3}\end{array}$ & $\begin{array}{c}\text { Hemolysins } \\
\text { Genes }\end{array}$ & $\begin{array}{l}\text { MSCRAMMs } \\
\text { Genes }\end{array}$ & $\begin{array}{c}\text { Immune } \\
\text { Evasion Genes }\end{array}$ \\
\hline $\begin{array}{l}\text { CC5-MRSA-IV } \\
\text { (Maltese clone)/ } \\
\text { ST149; t010, agr } \\
\text { group II }\end{array}$ & B-AoC-SA1 & $\begin{array}{c}17 \text { March } 2016 \\
\text { S1 }\end{array}$ & PEN, FOX, FUS & $\begin{array}{c}\text { mecA, blaZ, blaI, } \\
\text { blaR, fusC } \\
\text { (Q6GD50) }\end{array}$ & $\begin{array}{c}t s t 1+, \text { pvl-, et } A-, \\
\text { etB-, etD- }\end{array}$ & $\begin{array}{l}\text { lukF, lukS, lukD, } \\
\quad \operatorname{lukE,}, \operatorname{lukY}\end{array}$ & $\begin{array}{l}\text { sea, sec, sel, } \\
\text { egc-cluster }\end{array}$ & $\begin{array}{l}\text { hl, hla, hllll, } \\
\text { hlb, hlgA }\end{array}$ & $\begin{array}{c}\text { bbp, clfA, ebh, ebpS, } \\
\text { eno, fib, fnbA, fnbB, } \\
\text { map, sas }, \text { sdrC } \\
s d r D, v w b\end{array}$ & $s a k, s c n$ \\
\hline $\begin{array}{l}\text { CC5-MRSA-IV } \\
\text { (Maltese clone)/ } \\
\text { ST149; t010, agr } \\
\text { group II }\end{array}$ & B-AoC-SA2 & $\begin{array}{l}1 \text { April } 2016 \\
\text { S5 }\end{array}$ & PEN, FOX, FUS & $\begin{array}{c}\text { mecA, blaZ, blaI, } \\
\text { blaR, fusC } \\
\text { (Q6GD50) }\end{array}$ & $\begin{array}{c}t s t 1+, \text { pvl-, et } A- \\
\text { et } B-, \text { etD- }\end{array}$ & $\begin{array}{l}\text { lukF, lukS, lukD, } \\
\text { lukE, lukY }\end{array}$ & $\begin{array}{l}\text { sea, sec, sel, } \\
\text { egc-cluster }\end{array}$ & $\begin{array}{l}\text { hl, hla, hllll, } \\
\text { hlb, hlgA }\end{array}$ & $\begin{array}{c}b b p, c l f A, c l f B, e b h, \\
e b p S, \text { eno, fib, fnbA, } \\
\text { fnbB, map, sasG, sdrC, } \\
\text { sdrD, vwb }\end{array}$ & $s a k, s c n$ \\
\hline $\begin{array}{l}\text { CC5-MRSA-IV } \\
\text { (Maltese clone)/ } \\
\text { ST149; t010, agr } \\
\text { group II }\end{array}$ & B-AoC-SA3 & $\begin{array}{c}16 \text { April } \\
\text { S9 }\end{array}$ & PEN, FOX, FUS & $\begin{array}{c}\text { mecA, blaZ, blaI, } \\
\text { blaR, fusC } \\
\text { (Q6GD50) }\end{array}$ & $\begin{array}{l}\text { tst1+, pvl-, et } A-, \\
\quad \text { etB-, etD- }\end{array}$ & $\begin{array}{l}\text { lukF, lukS, lukD, } \\
\text { lukE, lukY }\end{array}$ & $\begin{array}{l}\text { sea, sec, sel, } \\
\text { egc-cluster }\end{array}$ & $\begin{array}{l}\text { hl, hla, hllll, } \\
\text { hlb, hlgA }\end{array}$ & $\begin{array}{c}b b p, c l f A, c l f B, e b h, \\
e b p S, \text { eno, fib, fnbA, } \\
\text { fnbB, map, sasG, sdrC, } \\
\text { sdrD, vwb }\end{array}$ & $s a k, s c n$ \\
\hline $\begin{array}{l}\text { CC5-MRSA-IV } \\
\text { (Maltese clone)/ } \\
\text { ST149; t010, agr } \\
\text { group II }\end{array}$ & B-AoC-SA4 & $\begin{array}{l}17 \text { May } 2016 \\
\text { S14 }\end{array}$ & PEN, FOX, FUS & $\begin{array}{c}\text { mecA, blaZ, blaI, } \\
\text { blaR, fusC } \\
\text { (Q6GD50) }\end{array}$ & $\begin{array}{l}\text { tst1+, pvl-, et } A-\text {, } \\
\quad \text { etB-, etD- }\end{array}$ & $\begin{array}{l}\text { lukF, lukS, lukD, } \\
\quad l u k E, \text { lukY }\end{array}$ & $\begin{array}{l}\text { sea, sec, sel, } \\
\text { egc-cluster }\end{array}$ & $\begin{array}{l}\text { hl, hla, hllll, } \\
\text { hlb, hlgA }\end{array}$ & $\begin{array}{c}b b p, c l f A, c l f B, e b h, \\
e b p S, \text { eno, fib, fnbA, } \\
\text { fnbB, map, sasG }, s d r C, \\
s d r D, v w b\end{array}$ & sak, scn \\
\hline
\end{tabular}

${ }^{1}$ Isolation sites are available in Figure $1 ;{ }^{2}$ PEN, penicillin G, FOX, cefoxitin, FUS, fusidic acid; ${ }^{3}$ egc cluster includes to seg, sei, sem, sen and seo genes. 


\section{Discussion}

MRSA isolates are one of the main pathogens causing worldwide public health problems. They have disseminated, not only in the hospital setting, but also in the community. MRSA have also been reported among various animal species including companion animals, livestock, and wild animals in several countries [3]. In Algeria, the data on MRSA have been reported from patients admitted to hospital, while insufficient studies have so far been obtained regarding genotypes of MRSA strains isolated outside hospitals [34-36], especially from wild animals $[8,37,38]$.

Thus, we report in this study the first isolation of MRSA from bat guano in Algeria. The four MRSA isolates recovered in this study belonged to the same clone, ST149-MRSAIV-SCCfus, which was described for the first time in Malta [39,40]. It was also reported more recently in the United Arab Emirates [41]. Interestingly, this clone has never before been detected in extra-human niches. Moreover, the description of MRSA in bats is very rare [21,22]. We also observed that our isolates harbored tst gene. The presence of this toxinogenic marker in wild animals has been previously described in wild monkeys and apes [42], wild rabbits [43], red deer [44] and white storks [45]. It is noteworthy that these toxinogenic $S$. aureus strains are described in wild animals, mainly in regions where these strains have high prevalence in clinical settings. For example, PVL+ strains have been previously isolated from wildlife in Algeria [8] in a context of high rates among isolates from human [46]. The same trend was reported in Nigeria, where MSSA-PVL+ [19] and MRSA-PVL+ [21] isolates have been described in this PVL-endemic region. The tst gene was also highly described in Algeria in clinical settings [47] and in livestock [37], wildlife [8] and food products [48]. Altogether, these results suggest that bats could be a reservoir of toxinogenic S. aureus strains. Moreover, a recent study at the Aokas's cave reported the presence of carbapenemase-producing Enterobacterales (KPC- and OXA-48-producing Klebsiella pneumoniae) in bat guano [49]. This additional result suggests that the bat guano could serve as reservoir of MDR bacteria.

The origin of the MRSA isolates remains an important question. Several studies highlighted that water could be a source of dissemination in nature [50-52]. Besides the microbiota diversity in the gastrointestinal tract, the presence of bacteria and their antibiotic-resistance patterns could be also influenced by dietary habits of bats [53]. Notably, Algerian bat species are insectivorous [54]. The ingestion of insects could be an additional route of transmission of antibiotic-resistant bacteria [55]. Moreover, this situation is mainly related to the overuse of antibiotics and their existence in soil and wastewater [56], the low disinfection of sewage resulting in the bacterial contamination of wastewater treatment plant and the insufficient infection control measures. The colonization of wild animals with MRSA lineages has been noticed from animals in close contact with humans [57]. However, the direct mode of transmission remains unclear between bat guano and humans. Besides, S. aureus clones adapted to animals might undergo further host-adaptive evolutionary changes, favoring an epidemic spread of new and more virulent strains in the human population and vice versa. Two factors associated with $S$. aureus immune evasion determinants in humans (scn and sak) were present in our isolates. They are responsible for the human innate immune system modulation and are considered as adaptation mechanisms of $S$. aureus inside the human host [58]. Their presence suggests the possible human origin of these isolates.

The presence of MRSA strains from wildlife, especially from bats, is cause for alarm, with implications for animal reservoirs of resistant bacteria [59]. Interestingly, we identified that the four isolates harbored the fos $B$ gene, whereas they were not resistant to fosfomycin. This resistance can occur by emergence of chromosomal mutations and/or the acquisition by horizontal genes transfer of plasmid-bearing enzymes that inactivate fosfomycin. It has previously been described that mutations in murA (affecting the MurA affinity of fosfomycin), and $g l p T$ and $u h p T$ genes (encoding fosfomycin transport systems of bacteria) are more common and important to generate fosfomycin-resistant strains [60]. Moreover, fosfomycin activity can also be supplied by catalytic activity such as FosA, FosB, FosC and 
FosX [61-63]. Due to the longevity of bats (35 years), the detection of these MDR bacteria could explain the ability of bats to maintain these MRSA, develop persistent carriage and transmit them to animals or human by direct or indirect contamination (via droplets, mucus, saliva or feces produced by bats).

The major limitation of our study was the impossibility to associate isolates with individual bats and to estimate the prevalence of bats colonized by MRSA. However, we applied rigorous inclusion criteria to rule out a sampling bias. The four MRSA isolated in our study were obtained at different periods (although these periods all fell over spring) on fresh fecal pellets collected on swabs in different parts of the cave. Bats are a protected species in Algeria, thus sampling methods had to be limited to guano collection or samples performed on recently dead animals.

\section{Conclusions}

Bats represent reservoir hosts of bacteria of significance for human health. These microorganisms can cross the species barrier to infect humans and animals. Studies on the importance of bats as reservoir of microorganisms are rare. This study highlighted that bat guano could be considered as a source of MRSA in Algeria. Their presence in a secluded area reinforces the extreme diversification of the diffusion of MRSA isolates. This wide dissemination outside of the clinical setting may represent an emerging risk for public health.

Supplementary Materials: The following are available online at https: / www.mdpi.com/article / 10.3390/microorganisms9112264/s1, Table S1: Antibiotic susceptibility profile of S. aureus strains isolated from Aokas's cave (Bejaia, Algeria).

Author Contributions: Conceptualization, A.M., A.T., A.S. and J.-P.L.; methodology, A.M., A.T., C.D.-R and J.-P.L.; software, A.M. and A.Y.M.; validation, A.M., A.T., C.D.-R., A.S. and J.-P.L.; formal analysis, A.M., A.P., A.Y.M. and C.D.-R.; investigation, A.M., A.P. and C.D.-R.; resources, A.M., A.T., A.Y.M., M.A., C.D.-R. and J.-P.L.; data curation, A.M., A.T., A.P., C.D.-R. and J.-P.L.; writing—original draft preparation, A.M. and J.-P.L.; writing—review and editing, A.T., A.P., A.Y.M., M.A., C.D.-R. and A.S.; visualization, A.M., A.P. and C.D.-R.; supervision, A.T. and J.-P.L.; project administration, J.-P.L.; funding acquisition, A.T., A.S. and J.-P.L. All authors have read and agreed to the published version of the manuscript.

Funding: This research was funded by INSERM, grant U1047 and Campus France, 17MDU980 and 73-PROFAS B+.

Institutional Review Board Statement: No ethical clearance was needed in this study as no animals were captured, nor were invasive samples taken.

Informed Consent Statement: Not applicable.

Data Availability Statement: Raw reads of newly sequenced MRSA strains are available under the BioProject number PRJNA734263 and assembled genomes SAMN19487653, SAMN19487654 and SAMN19487655.

Acknowledgments: We thank Sarah Kabani for her editing assistance.

Conflicts of Interest: The authors declare no conflict of interest.

\section{References}

1. Igrejas, G.; Correia, S.; Silva, V.; Hébraud, M.; Caniça, M.; Torres, C.; Gomes, C.; Nogueira, F.; Poeta, P. Planning a One Health Case Study to Evaluate Methicillin resistant Staphylococcus aureus and its economic burden in Portugal. Front. Microbiol. 2018, 9, 2964. [CrossRef]

2. Oliveira, D.; Borges, A.; Simões, M. Staphylococcus aureus toxins and their molecular activity in infectious diseases. Toxins 2018, 10, 252. [CrossRef] [PubMed]

3. Aires-de-Sousa, M. Methicillin-resistant Staphylococcus aureus among animals: Current overview. Clin. Microbiol. Infect. 2017, 23, 373-380. [CrossRef] [PubMed]

4. Lakhundi, S.; Zhang, K. Methicillin-resistant Staphylococcus aureus: Molecular characterization, evolution, and epidemiology. Clin. Microbiol. Rev. 2018, 31, e00020-18. [CrossRef] [PubMed] 
5. Turner, N.A.; Sharma-Kuinkel, B.K.; Maskarinec, S.A.; Eichenberger, E.M.; Shah, P.P.; Carugati, M.; Holland, T.L.; Fowler, V.G., Jr. Methicillin-resistant Staphylococcus aureus: An overview of basic and clinical research. Lancet Infect. Dis. 2019, 17, 203-218. [CrossRef]

6. Tong, S.Y.; Davis, J.S.; Eichenberger, E.; Holland, T.L.; Fowler, V.G., Jr. Staphylococcus aureus infections: Epidemiology, pathophysiology, clinical manifestations, and management. Clin. Microbiol. Rev. 2015, 28, 603-661. [CrossRef] [PubMed]

7. Morgan, M. Methicillin-resistant Staphylococcus aureus and animals: Zoonosis or humanosis? J. Antimicrob. Chemother. 2008, 62, 1181-1187. [CrossRef] [PubMed]

8. Mairi, A.; Touati, A.; Pantel, A.; Zenati, K.; Yahiahoui-Martinez, A.; Dunyach-Remy, C.; Sotto, A.; Lavigne, J.P. Distribution of toxinogenic methicillin-resistant and methicillin-susceptible Staphylococcus aureus from different ecological niches in Algeria. Toxins 2019, 11, 500. [CrossRef] [PubMed]

9. Moratelli, R.; Calisher, C.H. Bats and zoonotic viruses: Can we confidently link bats with emerging deadly viruses? Mem. Inst. Oswaldo Cruz 2015, 110, 1-22. [CrossRef]

10. Thiagavel, J.; Cechetto, C.; Santana, S.E.; Jakobsen, L.; Warrant, E.J.; Ratcliffe, J.M. Auditory opportunity and visual constraint enabled the evolution of echolocation in bats. Nat. Commun. 2018, 9, 98. [CrossRef]

11. Boyles, J.G.; Cryan, P.M.; McCracken, G.F.; Kunz, T.H. Conservation. Economic importance of bats in agriculture. Science 2011, 332, 41-42. [CrossRef]

12. Kamani, J.; Baneth, G.; Mitchell, M.; Mumcuoglu, K.Y.; Gutiérrez, R.; Harrus, S. Bartonella species in bats (Chiroptera) and bat flies (Nycteribiidae) from Nigeria, West Africa. Vector Borne Zoonotic Dis. 2014, 14, 625-632. [CrossRef] [PubMed]

13. Allocati, N.; Petrucci, A.G.; Di Giovanni, P.; Masulli, M.; Di Ilio, C.; De Laurenzi, V. Bat-man disease transmission: Zoonotic pathogens from wildlife reservoirs to human populations. Cell Death Discov. 2016, 2, 16048. [CrossRef]

14. Cicuttin, G.L.; De Salvo, M.N.; La Rosa, I.; Dohmen, F.E.G. Neoricketssia risticii, Rickettsia sp. and Bartonella sp. in Tadatida brasiliensis bats from Buenos Aires, Argentina. Comp. Immunol. Infect. Dis. 2017, 52, 1-5. [CrossRef] [PubMed]

15. Dietrich, M.; Mühldorfer, K.; Tortosa, P.; Markotter, W. Leptospira and bats: Story of an emerging friendship. PLoS Pathog. 2015, 11, e1005176. [CrossRef] [PubMed]

16. Akobi, B.; Aboderin, O.; Sasaki, T.; Shittu, A. Characterization of Staphylococcus aureus isolates from faecal samples of the Straw-Coloured Fruit bat (Eidolon helvum) in Obafemi Awolowo University (OAU), Nigeria. BMC Microbiol. 2012, $12,279$. [CrossRef] [PubMed]

17. Galicia, M.M.; Buenrostro, A.; Garcia, J. Specific bacterial diversity in bats of different food guilds in Southern sierra Oaxaca, Mexico. Rev. Biol. Trop. 2014, 62, 1673-1681.

18. Held, J.; Gmeiner, M.; Mordmüller, B.; Matsiégui, P.B.; Schaer, J.; Eckerle, I.; Weber, N.; Matuschewski, K.; Bletz, S.; Schaumburg, F. Bats are reservoirs of Staphylococcus aureus complex in Gabon. Infect. Genet. Evol. 2017, 47, 118-120. [CrossRef]

19. Olatimehin, A.; Shittu, A.O.; Onwugamba, F.C.; Mellmann, A.; Becker, K.; Schaumburg, F. Staphylococcus aureus complex in the straw-colored fruit bat (Eidolon helvum) in Nigeria. Front. Microb. 2018, 9, 162. [CrossRef]

20. Fountain, K.; Roberts, L.; Young, V.; Barbon, A.; Frosini, S.M.; Lloyd, D.H.; Loeffler, A. Diversity of staphylococcal species cultured from captive livingstone's fruit bats (Pteropus livingstonii) and their environment. J. Zoo Wildl. Med. 2019, 50, 266-269. [PubMed]

21. Shittu, A.O.; Mellmann, A.; Schaumburg, F. Molecular characterization of Staphylococcus aureus complex from fomites in Nigeria. Infect. Genet. Evol. 2020, 85, 104504. [CrossRef] [PubMed]

22. Konieczna, I.; Durlik, M.; Kwinkowski, M.; Domański, J.; Markowski, J.; Kaca, W. Properties of bacterial microflora isolated from bat guano. Med. Weter. 2007, 63, 1626-1629.

23. European Committee on Antimicrobial Susceptibility. Available online: www.eucast.org (accessed on 30 June 2019 ).

24. Sahebnasagh, R.; Saderi, H.; Owlia, P. The prevalence of resistance to methicillin in Staphylococcus aureus strains isolated from patients by PCR method for detection of mecA and nuc genes. Iran. J. Public Health 2014, 43, 84-92.

25. Seemann, T. Prokka: Rapid prokaryotic genome annotation. Bioinformatics 2014, 30, 2068-2069. [CrossRef] [PubMed]

26. Chen, L.; Yang, J.; Yu, J.; Yao, Z.; Sun, L.; Shen, Y.; Jin, Q. VFDB: A reference database for bacterial virulence factors. Nucleic Acids Res. 2005, 33, D325-D328. [CrossRef] [PubMed]

27. Zankari, E.; Hasman, H.; Cosentino, S.; Vestergaard, M.; Rasmussen, S.; Lund, O.; Aarestrup, F.M.; Larsen, M.V. Identification of acquired antimicrobial resistance genes. J. Antimicrob. Chemother. 2012, 67, 2640-2644. [CrossRef] [PubMed]

28. Bortolaia, V.; Kaas, R.F.; Ruppe, E.; Roberts, M.C.; Schwarz, S.; Cattoir, V.; Philippon, A.; Allesoe, R.L.; Rebelo, A.R.; Florensa, A.R.; et al. ResFinder 4.0 for predictions of phenotypes from genotypes. J. Antimicrob. Chemother. 2020, 75, 3491-3500. [CrossRef] [PubMed]

29. Katoh, K.; Standley, D.M. MAFFT multiple sequence alignment software version 7: Improvements in performance and usability. Mol. Biol. Evol. 2013, 30, 772-780. [CrossRef] [PubMed]

30. Page, A.J.; Taylor, B.; Delaney, A.J.; Soares, J.; Seemann, T.; Keane, J.A.; Harris, S.R. SNP-sites: Rapid efficient extraction of SNPs from multi-FASTA alignments. Microb. Genom. 2016, 2, e000056. [CrossRef] [PubMed]

31. Cingolani, P.; Platts, A.; Wang, L.L.; Coon, M.; Nguyen, T.; Wang, L.; Land, S.J.; Lu, X.; Ruden, D.M. A program for annotating and predicting the effects of single nucleotide polymorphisms, SnpEff: SNPs in the genome of Drosophila melanogaster strain w1118; iso-2; iso-3. Fly 2012, 6, 80-92. [CrossRef]

32. Alikhan, N.F.; Petty, N.K.; Ben Zakour, N.L.; Beatson, S.A. BLAST Ring Image Generator (BRIG): Simple prokaryote genome comparisons. BMC Genom. 2011, 12, 402. [CrossRef] [PubMed] 
33. Ankrum, A.; Hall, B.G. Population dynamics of Staphylococcus aureus in cystic fibrosis patients to determine transmission events by use of whole-genome sequencing. J. Clin. Microbiol. 2017, 55, 2143-2152. [CrossRef] [PubMed]

34. Ruppé, E.; Barbier, F.; Mesli, Y.; Maiga, A.; Cojocaru, R.; Benkhalfat, M.; Benchouk, S.; Hassaine, H.; Maiga, I.; Diallo, A.; et al. Diversity of staphylococcal cassette chromosome mec structures in methicillin-resistant Staphylococcus epidermidis and Staphylococcus haemolyticus strains among outpatients from four countries. Antimicrob. Agents Chemother. 2009, 53, 442-449. [CrossRef] [PubMed]

35. Titouche, Y.; Hakem, A.; Houali, K.; Meheut, T.; Vingadassalon, N.; Ruiz-Ripa, L.; Salmi, D.; Chergui, A.; Chenouf, N.; Hennekinne, J.A.; et al. Emergence of methicillin-resistant Staphylococcus aureus (MRSA) ST8 in raw milk and traditional dairy products in the Tizi Ouzou area of Algeria. J. Dairy Sci. 2019, 102, 6876-6884. [CrossRef]

36. Akkou, M.; Bouchiat, C.; Antri, K.; Bes, M.; Tristan, A.; Dauwalder, O.; Martins-Simoes, P.; Rasigade, J.P.; Etienne, J.; Vandenesch, F.; et al. New host shift from human to cows within Staphylococcus aureus involved in bovine mastitis and nasal carriage of animal's caretakers. Vet. Microbiol. 2018, 223, 173-180. [CrossRef] [PubMed]

37. Agabou, A.; Ouchenane, Z.; Ngba Essebe, C.; Khemissi, S.; Chehboub, M.T.E.; Chehboub, I.B.; Sotto, A.; Dunyach-Remy, C.; Lavigne, J.P. Emergence of nasal carriage of ST80 and ST152 PVL+ Staphylococcus aureus isolates from Livestock in Algeria. Toxins 2017, 9, 303. [CrossRef] [PubMed]

38. Achek, R.; Hotzel, H.; Nabi, I.; Kechida, S.; Mami, D.; Didouh, N.; Tomaso, H.; Neubauer, H.; Ehricht, R.; Monecke, S.; et al. Phenotypic and molecular detection of biofilm formation in Staphylococcus aureus isolated from different sources in Algeria. Pathogens 2020, 9, 153. [CrossRef]

39. Scicluna, E.A.; Shore, A.C.; Thürmer, A.; Ehricht, R.; Slickers, P.; Borg, M.A.; Coleman, D.C.; Monecke, S. Characterisation of MRSA from Malta and the description of a Maltese epidemic MRSA strain. Eur. J. Clin. Microbiol. Infect. Dis. 2010, 29, 163-170. [CrossRef] [PubMed]

40. Scerri, J.; Monecke, S.; Borg, M.A. Prevalence and characteristics of community carriage of methicillin-resistant Staphylococcus aureus in Malta. J. Epidemiol. Glob. Health 2013, 3, 165-173. [CrossRef] [PubMed]

41. Senok, A.; Nassar, R.; Kaklamanos, E.G.; Belhoul, K.; Abu Fanas, S.; Nassar, M.; Azar, A.J.; Müller, E.; Reissig, A.; Gawlik, D.; et al. Molecular characterization of Staphylococcus aureus isolates associated with nasal colonization and environmental contamination in academic dental clinics. Microb. Drug Resist. 2020, 26, 661-669. [CrossRef]

42. Roberts, M.C.; Joshi, P.R.; Monecke, S.; Ehricht, R.; Müller, E.; Gawlik, D.; Diezel, C.; Braun, S.D.; Paudel, S.; Acharya, M.; et al. Staphylococcus aureus and methicillin resistant $S$. aureus in Nepalese primates: Resistance to antimicrobials, virulence, and genetic lineages. Antibiotics 2020, 9, 689. [CrossRef]

43. Ruiz-Ripa, L.; Alcalá, L.; Simón, C.; Gómez, P.; Mama, O.M.; Rezusta, A.; Zarazaga, M.; Torres, C. Diversity of Staphylococcus aureus clones in wild mammals in Aragon, Spain, with detection of MRSA ST130-mecC in wild rabbits. J. Appl. Microbiol. 2019, 127, 284-291. [CrossRef]

44. Gómez, P.; Lozano, C.; González-Barrio, D.; Zarazaga, M.; Ruiz-Fons, F.; Torres, C. High prevalence of methicillin-resistant Staphylococcus aureus (MRSA) carrying the mecC gene in a semi-extensive red deer (Cervus elaphus hispanicus) farm in Southern Spain. Vet. Microbiol. 2015, 177, 326-331. [CrossRef] [PubMed]

45. Gómez, P.; Lozano, C.; Camacho, M.C.; Lima-Barbero, J.F.; Hernández, J.M.; Zarazaga, M.; Höfle, Ú.; Torre, C. Detection of MRSA ST3061-t843-mecC and ST398-t011-mecA in white stork nestlings exposed to human residues. J. Antimicrob. Chemother. 2016, 71, 53-57. [CrossRef] [PubMed]

46. Mairi, A.; Touati, A.; Lavigne, J.P. Methicillin-Resistant Staphylococcus aureus ST80 clone: A systematic review. Toxins 2020, $12,119$. [CrossRef] [PubMed]

47. Antri, K.; Rouzic, N.; Boubekri, I.; Dauwalder, O.; Beloufa, A.; Ziane, H.; Djennane, F.; Neggazi, M.; Benhabyles, B.; Bes, M.; et al. High prevalence of community- and hospital-acquired infections of methicillin-resistant Staphylococcus aureus containing PantonValentine leukocidin gene in Algiers. Pathol. Biol. 2010, 58, e15-e20. [CrossRef] [PubMed]

48. Chaalal, W.; Chaalal, N.; Bourafa, N.; Kihal, M.; Diene, S.M.; Rolain, J.M. Characterization of Staphylococcus aureus isolated from food products in Western Algeria. Foodborne Pathog. Dis. 2018, 15, 353-360. [CrossRef] [PubMed]

49. Gharout-Sait, A.; Touati, A.; Ahmim, M.; Brasme, L.; Guillard, T.; Agsous, A.; de Champs, C. Occurrence of carbapenemaseproducing Klebsiella pneumoniae in Bat Guano. Microb. Drug Resist. 2019, 25, 1057-1062. [CrossRef] [PubMed]

50. Makowska, N.; Bresa, K.; Koczura, R.; Philips, A.; Nowis, K.; Mokracka, J. Urban wastewater as a conduit for pathogenic Gram-positive bacteria and genes encoding resistance to $\beta$-lactams and glycopeptides. Sci. Total Environ. 2021, 765, 144176. [CrossRef]

51. Adesoji, T.O.; Egyir, B.; Shittu, A.O. Antibiotic-resistant staphylococci from the wastewater treatment plant and grey-water samples in Obafemi Awolowo University, Ile-Ife, Nigeria. J. Water Health 2020, 18, 890-898. [CrossRef] [PubMed]

52. Boopathy, R. Presence of Methicillin resistant Staphylococcus aureus (MRSA) in sewage treatment plant. Bioresour. Technol. 2017, 240, 144-148. [CrossRef]

53. Daniel, D.S.; Ng, Y.K.; Chua, E.L.; Arumugam, Y.; Wong, W.L.; Kumaran, J.V. Isolation and identification of gastrointestinal microbiota from the short-nosed fruit bat Cynopterus brachyotis brachyotis. Microbiol. Res. 2013, 168, 485-496. [CrossRef]

54. Ahmim, M. Current status, distribution and conservation status of Algerian bats (Mammalia: Chiroptera). J. Threat. Taxa 2017, 9, 9723-9733. [CrossRef]

55. Onwugamba, F.C.; Fitzgerald, J.R.; Rochon, K.; Guardabassi, L.; Alabi, A.; Kühne, S.; Grobusch, M.P.; Schaumburg, F. The role of 'filth flies' in the spread of antimicrobial resistance. Travel Med. Infect. Dis. 2018, 22, 8-17. [CrossRef] [PubMed] 
56. Karakonstantis, S.; Kalemaki, D. Antimicrobial overuse and misuse in the community in Greece and link to antimicrobial resistance using methicillin-resistant S. aureus as an example. J. Infect. Public Health 2019, 12, 460-464. [CrossRef] [PubMed]

57. Schaumburg, F.; Mugisha, L.; Peck, B.; Becker, K.; Gillespie, T.R.; Peters, G.; Leendertz, F.H. Drug-resistant human Staphylococcus aureus in sanctuary apes pose a threat to endangered wild ape populations. Am. J. Primatol. 2012, 74, 1071-1075. [CrossRef]

58. Senghore, M.; Bayliss, S.C.; Kwambana-Adams, B.A.; Foster-Nyarko, E.; Manneh, J.; Dione, M.; Badji, H.; Ebruke, C.; Doughty, E.L.; Thorpe, H.A.; et al. Transmission of Staphylococcus aureus from humans to green monkeys in the Gambia as revealed by whole-genome sequencing. Appl. Environ. Microbiol. 2016, 82, 5910-5917. [CrossRef] [PubMed]

59. Cláudio, V.C.; Gonzalez, I.; Barbosa, G.; Rocha, V.; Moratelli, R.; Rassy, F. Bacteria richness and antibiotic-resistance in bats from a protected area in the Atlantic Forest of Southeastern Brazil. PLoS ONE 2018, 13, e0203411. [CrossRef]

60. Fu, Z.; Ma, Y.; Chen, C.; Guo, Y.; Hu, F.; Liu, Y.; Xu, X.; Wang, M. Prevalence of fosfomycin resistance and mutations in murA, $g l p T$, and $u h p T$ in methicillin-resistant Staphylococcus aureus strains isolated from blood and cerebrospinal fluid samples. Front. Microbiol. 2016, 6, 1544. [CrossRef] [PubMed]

61. Fillgrove, K.; Pakhomova, S.; Schaab, M.R.; Newcomer, M.E.; Armstrong, R.N. Structure and mechanism of the genomically encoded fosfomycin resistance protein, FosX, from Listeria monocytogenes. Biochemistry 2007, 46, 8110-8120. [CrossRef]

62. García, P.; Arca, P.; Evaristo, S.J. Product of $f \circ s C$, a gene from Pseudomonas syringae, mediates fosfomycin resistance by using ATP as cosubstrate. Antimicrob. Agents Chemother. 1995, 39, 1569-1573. [CrossRef] [PubMed]

63. Lee, S.Y.; Park, Y.J.; Yu, J.K.; Jung, S.; Kim, Y.; Jeong, S.H.; Arakawa, Y. Prevalence of acquired fosfomycin resistance among extended-spectrum $\beta$-lactamase-producing Escherichia coli and Klebsiella pneumoniae clinical isolates in Korea and IS26-composite transposon surrounding fosA3. J. Antimicrob. Chemother. 2012, 67, 2843-2847. [CrossRef] [PubMed] 